\title{
W. Ross Livingston, Curator of British Documents
}

H O M E R L. C A L K I N

"Squire Livingston," as he was affectionately called by many of his friends and students, was a familiar sight at The University of Iowa for more than 50 years. There was no mistaking him as he walked across the campus.

Livingston seemed never to be without a cigar or pipe. Some called his cigars "cheap" or "ubiquitous." They were indeed inexpensive, at least in 1932 when he ordered 50 Clubman Perfectos from Tampa, Florida, for $\$ 6.80$. His grandson recalled that they smelled "something like burning leaves with something sweet added." A second distinguishing mark was his hat, a Western style by Stetson. Thirdly, there was his distinctive stride; some people swore that he had probably acquired it while he followed a walking plow in his native Missouri.

Walter Ross Livingston was born on October 14, 1893, in Miller County, Missouri. He died in Coralville, Iowa, on December 30, 1978. Throughout his life he was always interested in his native state and returned to his "ranch" in the Ozarks for relaxation whenever possible.

No one label can be used to characterize him fully. He was always interested in building up the resources of The University of Iowa libraries. He was a teacher, editor, associate with politicians and statesmen in the United States and the British Empire, aspiring diplomat, politician, soldier, and some would say a bit of an eccentric.

When Livingston was preparing to enter military service during World War I, Jean Campbell, a teacher of romance languages at Knox College, wrote him:

I bought a small diary with the intention of wishing it onto you with the plea that you should keep at least a brief record of all that 
you do from your entrance into the service-you will be glad to read it to your grand-children! ... Or do you scom the idea altogether?

Not only did he use this first diary, but he continued to use one for nearly every year after that. In addition he kept much, if not all, of his correspondence. With these papers, now in the University Archives, The University of Iowa Libraries, it is possible to know much about this unusual man and his varied activities.

Ross began his long career by teaching in the rural schools in the Ozark Mountains of southern Missouri for four years before he graduated from high school at the Iberia Academy in 1916 at the age of 23. During the summer following graduation he worked in the Kansas wheat fields to earn money to supplement a scholarship that fall at Knox College in Galesburg, Illinois.

Livingston's studies at Knox College were interrupted by military service. The Examination Board of the War Department directed him to appear for physical and mental examinations on January 23, 1918, prior to assignment to the School of Military Aeronautics. He completed the school year before reporting to Austin, Texas, for several months of training. At the end of this he noted in his diary: "Graduated! No bust or no low grades. I feel great about it."

He was transferred to Fortress Monroe for the observer's course in heavy artillery. From there he went to Post Field, Oklahoma, for training and commissioning as an officer in December 1918. On January 17,1919 , he completed his military service, and he left for home.

His elation was great. "Am done with army forever I hope. I hopel" However, he was to change his attitude with the outbreak of World War II. Again, he would be eager for military service, this time, in his terms, as a "retread."

After leaving the army, Livingston returned to Knox College, where he received his A.B. degree in 1919. He then received a scholarship in history with a stipend of $\$ 200$ at the University of Missouri, where he earned his A.M. degree the following year.

During the spring of 1920 , while completing his master's degree. he learned something of the difficulties that faced students when seeking employment. He wrote many letters regarding teaching positions, for the most part in the western and northwestern sections of the United States. He also sought work in the Bureau of Insular Affairs of the War Department, in the Chautauqua movement, with wholesalers, and as an educational missionary for the Board of Foreign Missions of the Methodist Episcopal Church. He even sought a job for the summer with the Fuller Brush Company. This experi- 
ence helped him later to appreciate what his own students were to encounter, particularly during the depression years of the 1930s.

On May 24, Pomona College, one of those to which he had applied, notified him that he had been appointed to teach economics and history there for two years. About three weeks later he was offered and accepted a position as history teacher for the summer of 1920 at Southeast Missouri State College, Cape Girardeau, Missouri.

While at Pomona College he began to realize that he needed to have more than a master's degree if he expected to succeed in his chosen field of teaching. After three years at Pomona, Frederic L. Paxson, chairman of the Department of History at the University of Wisconsin, offered Livingston a fellowship for 1923-24.

He received free tuition and a salary of $\$ 500$ for teaching the equivalent of three hours in freshman courses. Mrs. Livingston helped by teaching school at Spencer, Wisconsin. The following year Livingston's salary was doubled. An arrangement had been made by him "to carry double work, teaching eight sections" of history.

While a graduate student at Wisconsin, he studied under Winfred T. Root the constitutions of the American colonies. This was too limited an approach for Livingston, who wanted to explore the constitutional processes in the British colonies as well. During the summers he went to the Canadian Archives in Ottawa to do research on the Canadian provinces, particularly responsible government in Nova Scotia.

In 1925 Root, newly appointed head of the history department at The University of Iowa, invited Livingston to accompany him from Wisconsin to accept a position as instructor in history. Livingston did this and thus began a many-faceted career that was to become international in nature, reach into many places, and touch many people's lives. His was "a vivid presence" that would leave many lasting impressions.

Livingston taught courses in Canadian history and American foreign relations when he first came to Iowa. In addition he wanted to teach constitutional and British history-British meaning to him the British Empire and Commonwealth. However, beyond some British parliamentary documents, there were few, if any, research materials available in the University Libraries.

During late 1925 or early 1926, Ross wrote Walter A. Jessup, president of the University, a memorandum in which he suggested that the University "establish a Bureau of Foreign Relations here and bring to this campus all the published documents from every government in the world." Livingston's reasoning was that Iowa was the 
"heart of America," and "here will be the most important factor in diplomacy in the centuries that lie ahead." Jessup said it was a good idea, but, "See what you can do with the British." This was the beginning of Livingston's career as "Curator of British Documents" at The University of Iowa.

Livingston immediately began his efforts to secure documents pertaining to the British Empire. As early as February 19, 1926, he was writing to the minister of lands and agriculture in New Zealand for the journals and debates of the Parliament from its beginnings. Noting that The University of lowa was one of the largest universities in the Middle West, he wrote, "We should appreciate your cooperation in developing in this country a deeper appreciation of the British Empire and a better knowledge of New Zealand."

At the same time he wrote Gilbert Tucker of Christ College, Cambridge University, asking for names and addresses of people or organizations from whom he might get documents of the Irish Free State and India. He added: "These hands of mine are reaching across the sea to Melbourne, Wellington and Pretoria, and when I am through, the whole Empire will have met here in Iowa City, 'out where the West begins,' and 'the tall corn grows."

Within two months-February to April 1926-Livingston had written numerous people regarding his project. These included librarians and political leaders in India, Ireland, Australia, New Zealand, and the Union of South Africa.

In writing to a member of the Legislative Assembly at Madras, India, he emphasized that the United States "is playing and is bound to play in the future in the affairs of the Orient and the Pacific world" an important role. He noted that public opinion in America "is determined to a great extent by the people of this Mid-Continental region; and ... if we are to have a proper understanding of the Oriental world," the documents of the larger nations had to be available for study.

Getting the project established was frequently drawn out for several months, even years in some cases. Livingston's experience with the Union of South Africa is a good example.

He wrote the secretary of the interior of South Africa on February 19, 1926. He followed this with a letter to Jan Christiaan Smuts, former prime minister, on March 6. He suggested to Smuts that opposition to the attempt of President Woodrow Wilson "to build a new world order [through the League of Nations] resulted primarily from the attitude of this Middle West." Therefore, Livingston hoped to develop a new attitude, "the development of a knowledge and ap- 
preciation of the present [British] Commonwealth of Nations." This would in turn help to change public opinion in America. It was for this purpose that he was seeking Smuts's support in securing the published documents of South Africa.

Livingston's letters did not bring immediate results, but persistence was to bring results eventually. Smuts replied that he sympathized with Livingston's request and hoped that the secretary of the interior would give a favorable answer. He promised to see him and to urge him to comply with Livingston's wishes.

The secretary in turn replied that gratis copies of parliamentary journals could not be sent. The parliamentary librarian, Paul Ribbink, had suggested that The University of Iowa might have published works on the political and social sciences. If this were the case, an exchange might be worked out.

Apparently Livingston concluded that it would help if publications of the state of Iowa were included in the exchange agreement. He wrote, "I went to [Benjamin] Shambaugh [head of the political science department] because he knew the authorities in Des Moines. He was very gracious in his interest in my project." Robert Henderson, superintendent of printing for the state of Iowa, complied with Shambaugh's request and sent the Official Register and other state documents to the Library of Parliament in Cape Town.

On July 20, 1926, Livingston optimistically wrote J. B. Kaiser, director of the University Libraries: "This is to inform you that an exchange of published documents has been arranged between the State of Iowa, and the Union of South Africa. If the arrangements are carried out, we should begin to receive these publications by September or October." Such was not to be the case.

Ribbink wrote Livingston on December 30, 1926, that "a little confusion has arisen" regarding the nature of publications that he would like to receive. "These are in the nature of doctoral dissertations in the various social and political sciences, rather than the type which you have sent us." In exchange he would send the year book, debates, and statutes of South Africa.

To comply with this request, Grace Wormer, acting director of the University Libraries, sent copies of 12 dissertations to Ribbink. At the same time the South African parliamentary library was added to the permanent mailing list for doctoral dissertations at Iowa. Ribbink again replied that this was not enough to form the basis for an exchange.

After a year and a half, Livingston had not been successful in procuring any agreement for sending publications to him. In August 
1927, he sent follow-up letters to Australia, New Zealand, Ireland, and South Africa. Again he wrote Smuts, asking him, "May I request again your assistance in smoothing out any difficulties which may still stand in the way of this arrangement?"

Ribbink now agreed to send the latest issues of those publications which he had mentioned earlier. However, to establish a regular exchange for the future, he wanted publications that dealt with the United States as a whole. "The State publications of Iowa are hardly the kind of American publications which would be most sought after here but reference works dealing with the United States would form the basis of an exchange for the publications you desire."

Arthur Wadsworth, librarian of the Australian parliament, also reacted negatively at this time. He did not think that the publications of Iowa and the University had "sufficient interest to us" to arrange an exchange.

There was one bright spot. On September 23, 1927, Colin O'Hurcharde, clerk of the Irish Dail, wrote that the statutes of Ireland for the years 1923 to 1926 and bound volumes of the Debates from the beginning were being forwarded. The volume of acts passed in 1922 would be sent as soon as it was published. Livingston noted in his diary for October 18 that 12 packages of books from Ireland had been received.

Having been able to reach an agreement with the Irish Free State, Livingston was more determined to secure publications that would satisfy the requirements of other nations in exchange agreements. $\mathrm{He}$ enlisted the assistance of Robert Rienow, dean of men at the University, to write E. R. Harlan, curator of the Department of History and Archives in Des Moines, regarding the availability of that organization's publications for exchange.

He also wrote Daniel T. Steck, U.S. senator from Iowa, to learn if bound volumes of the Congressional Record could be made available for his project. Steck was willing to get him several sets for this purpose. Livingston at once asked that one set be sent to South Africa. He felt that "as many as six sets in all . . . would suffice for our purposes."

By the end of 1927 Livingston's efforts began to bring results. Forty-two volumes of the Legislative Assembly and 18 volumes of the Legislative Council in Natal were available for a nominal sum. During the next year The University of Iowa was placed on the exchange list for publications from Newfoundland and Ontario, the Transvaal, Australia, and South Africa. While in Toronto and Ottawa 
in the summer of 1928 , he made arrangements to get materials that had been previously purchased.

In September Carl Seashore, dean of the Graduate College, wrote Grace Wormer that $\$ 500$, or as much of this as was needed, would be made available from the research equipment fund of the Graduate College. This money would be used to defray "special expenses connected with the exchange service . . . begun by Dr. Livingston. This grant is made on condition that Dr. Livingston is given suitable recognition in the office of the Librarian, and such material and personal assistance as may facilitate the effective development of this project."

Miss Wormer replied that it was the "consensus ... of the Library Staff ... that we are not yet in a position to launch on a big scale a campaign of exchange. . ." She thought it would be highly desirable if the library's budget could be increased $\$ 2,000$ annually to hire a staff member with library training and experience to be in charge of an exchange section in the library. Livingston noted on his copy of the letter: "Library training \& experience for diplomatic task!"

Wormer further stated that she knew of no library where exchange relations were handled or "even initiated by anyone outside of the Library staff." She could see where "such an arrangement may lead to much confusion and many complications." Livingston's comment: "Evidently does not wish it." His overall remark about the letter was: "This leaves me in the clear," obviously to pursue his own exchange program outside of the library organization.

Three years later he was appointed "Curator of British Documents," a title he proudly used from that time on. He continued to receive the documents until 1964, when an agreement was reached between the library and Livingston that documents for which he had arranged exchange agreements should now be sent to the Government Documents Department of The University of Iowa Libraries. The address to be used would continue to include the notation: "Attn: Professor W. Ross Livingston, Curator of British Documents."

Livingston's efforts to procure documents from India were unsuccessful for a number of years. Finally, in December 1929 he wrote to Jawaharlal Nehru, president of the All-India Congress Committee. Nehru replied that he would gladly send all available materials of the National Congress. By March 4, 1930, records of the congress had been received by Livingston. 
During his research trip to New Zealand in 1930, Livingston arranged for the University to receive the Hansard debates of that country. His efforts were not limited to arranging for parliamentary documents from Ireland, New Zealand, Canada, Australia, India, and South Africa. In 1934 he began to write each of the provincial governments in Canada-such as British Columbia, Manitoba, Alberta, and the others-as well as the provincial secretary of Jamaica regarding their documents. As in the case of his earlier attempts, he was usually successful.

By that year (1934) the News Letter of the Department of History reported with pride:

For the study of institutions and the workings of government, the field of the British Commonwealth is of signal importance; not only because of the wealth of recent constitutional development which it includes but also because of the kinship, similarity, and geographical proximity to the American Republic. In origin and in purpose the Commonwealth and the Republic are sister national experiments. . . . The University of Iowa has realized the importance of this relationship and has builded into its Library great collections of documentary sources of Empire and Dominion history.

\section{The News Letter continued:}

In recent years the greatest growth in the facilities for the study of British history has been in the field of the great Dominions. The Library now contains nearly 2,500 volumes of official government publications dealing with the legal and political history and parliamentary development of these British nations.

In spite of Jessup's advice to limit his efforts to the British Empire, Livingston did not limit himself to this. In 1932 he was able to obtain pamphlets from the Bureau of Information of the Japanese Chamber of Commerce in New York. These pertained to the Japanese-China situation.

In writing to the president of the Chamber of Commerce, Livingston stressed the fact that he was receiving "practically all of the documentary material . . . from all of the British dominions." $\mathrm{He}$ suggested that the Japanese government might be interested in cooperating in a similar effort regarding governmental developments in Japan. Y. Kumazawa, secretary of the chamber, replied that "such a collection will indeed be an important medium through which international understanding may be fostered." 
The Chamber of Commerce referred Livingston to the Japanese consulate in Chicago. The Japanese consul informed Livingston that practically all government publications were written in Japanese. Was The University of Iowa interested in publications in English only or those in Japanese as well? Livingston continued to be interested in trying to reach some agreement with Japan as late as 1939.

Following World War II, Livingston resumed his efforts to obtain government documents from other nations as well. Among those in which he was interested were the Republic of India following independence, the Gold Coast (later Ghana), Afghanistan, Pakistan, Northern Ireland, and Ceylon (Sri Lanka).

Livingston had become acquainted with John Sherman Cooper, former U.S. senator from Kentucky, during the war when both served in the same unit in Europe. When Cooper was appointed U.S. ambassador to the German Democratic Republic, Livingston wrote him about acquiring documents from the government of East Germany. Through these various efforts of Livingston, the University Library has been able to acquire publications from many of these countries to add to its already extensive collections.

Livingston was interested in other ways of increasing the holdings of the library at Iowa. On returning from the Public Archives of Canada in 1926, he stopped in Toronto to see the library of the late James Mavor, professor of political economy at the University of Toronto. He discussed with Dean Seashore, Dean Phillips, and Miss Wormer the possibility of purchasing the library, which consisted of approximately ten thousand bound volumes and twenty thousand unbound pamphlets and documents.

Iowa was willing to place a bookplate in each volume, indicating that the collection was a memorial to Mavor. In addition the University proposed to designate one of the University's fellowships as the Mavor fellowship to carry a stipend of $\$ 500$.

The Mavor library had been offered for $\$ 6,000, \$ 2,000$ cash and the remainder in four yearly payments. The University of Iowa wanted to know the Mavor family's best possible price for a payment in cash. The University never received a reply to this question. Instead, Wilfred Mavor, the son of Professor Mavor, informed Livingston that Iowa had lost out to Harvard University, which had made a larger offer.

Livingston was not only concerned with building up a collection of documents at The University of Iowa that would aid scholars interested in the development of the British Commonwealth. He was 
also interested in increasing his own knowledge in this field and in writing about it.

During the summer of 1924 in the Public Archives of Canada at Ottawa, he had worked on the beginnings of democratic government in the British Empire. This led him to the development of responsible government in Nova Scotia, a topic which became the subject of his doctoral dissertation at Wisconsin.

While in Ottawa, Dr. Arthur G. Doughty, Canadian archivist, permitted him to use correspondence between Lord Elgin and Earl Grey. The following summer Livingston returned to Ottawa, where he cooperated with Doughty in editing the Elgin-Grey correspondence for publication. This latter task was to continue for a few years after Livingston came to Iowa.

Livingston taught summer school at the University of Washington in 1929. This proved to be an important time for him. While he was there, Herbert Brookes, commissioner general for the Commonwealth of Australia to the United States, stopped at Seattle on his way to New York. Livingston attended a dinner for Mr. and Mrs. Brookes as a representative of the university. In recalling this event, Livingston said he got up to make a speech. He told the honored couple that they were welcome in the United States, "that they were just as much at home here as they would be anywhere in the BritishAmerican world, that we were their kind of people, and they were our kind of people. ..." The next day he accompanied Brookes in an interview with a Hearst reporter. This gave Livingston an opportunity to mention his book on responsible government in Nova Scotia.

A short time later he sent Brookes a copy. He wrote. "As far as I know it is the only study of development of the first responsible party government ever organized in the British Empire. . ." Brookes replied that "it is easily first among the historical studies of the evolution of our Empire." It will make "clear and definite the conception and realization of empire as developed in the English-speaking world."

The University of Iowa published Livingston's book, Responsible Government in Nova Scotia, in 1930. Herbert Brookes and John W. Davis, Democratic candidate for president in 1924, wrote forewords. One reviewer of the book stressed the fact that Livingston had relied almost exclusively on original and manuscript sources. "Herein lies the main contribution of his work." Another review stated that Livingston had "undoubtedly made a distinct contribution." The book 


\title{
UNIVERSITY OF IOWA STUDIES
}

\section{Studies in the Social Sciences}

\begin{tabular}{ll}
\hline \hline VOLUME IX & NUMBER 1 \\
\hline \hline
\end{tabular}

\section{RESPONSIBLE GOVERNMENT IN NOVA SCOTIA}

\author{
A Study of \\ The Constitutional beginnings of the \\ British Commonwealth
}

By

W. Ross Lrvineston, Ph.D.

PUBLISHED BY THE UNIVERSITY, IOWA CITY, IOWA

\section{Issued semi-monthly throughout the year. Entered at the post offloe at Iowa Cits, Iowa, as second class matter under the Act of Oetober 8, 1917 .}

W. Ross Livingston's Responsible Government in Nova Scotia was published in 1930 in a series of studies edited for The University of Iowa by Professor Louis Pelzer of the Department of History. Shown above is a copy from The University of Iowa Archives. 
had focused attention on a neglected field of the development of responsible government. The next year the University published Livingston's second work on responsible government, this one dealing with Prince Edward Island.

It was a much longer time before the Elgin-Grey correspondence was published. Livingston completed his work on the papers in 1926, but it would be 11 years before they appeared in print. In 1928 Livingston heard a rumor that "publication of the letters has been 'squashed' primarily because they had been edited by an American."

When the correspondence was finally published, it was without the footnotes, chapter organization, and other editorial work that Livingston had performed. In addition Livingston's name did not appear on the title page. It was stated instead in the introduction that "Three or more different plans for publication were successively considered, but none of these earlier proposals ever came to a final stage. ... In particular, mention should be made of the work done at this time by Professor W. Ross Livingston. ..."

It had been a labor of love for Livingston, who had provided secretarial assistance, obtained photostatic copies of documents, and did other things without being paid. Finally, in 1939, he received $\$ 500$ for his work, "heart-balm" as he expressed it.

To further his research on the British Empire, Livingston sought grants a number of times. In 1928 he tried to get a Social Science Research Council grant to go to England. He proposed to study responsible government there. He felt it was a necessary and inevitable development of the American constitutional system.

He wanted to spend several months in England, where he would investigate this topic in the papers and documents at the Public Record Office, the British Museum, and other depositories. Because of a lack of funds he did not receive a grant.

When this failed, he applied for a traveling fellowship from the Kahn Foundation of New York. He was supported by Walter A. Jessup and W. T. Root. Root thought the trip over much of the world "would be a fine thing for him. It would enable Livingston to see the British Empire and its relations to the rest of the world."

The trip that Livingston outlined for the Kahn Foundation was indeed an ambitious one. It would have taken him to most countries in all of the continents as well as the islands of the Caribbean and the Pacific. He planned to meet some of the leading citizens in each country as well as to mingle as much as possible with the common man. Again, a grant was not forthcoming. 
Two years later he applied for a grant from the Carnegie Corporation to go to Australia to study. His friend, Herbert Brookes, supported him in this endeavor. In April 1930 Livingston went to New York to see F. P. Keppel regarding his application.

Upon returning to Iowa City he submitted a statement to the Carnegie Corporation of his plan of study and research in Australia:

It is my purpose to study the nationalism of Australia as it emerged during the closing years of the 19th century, and as it developed during the period just preceding the World War. ... I shall endeavor to study the deeper springs of life of the people. I shall cultivate as far as possible contacts with her leaders, and do everything in my power to develop friendship and understanding between Australia and the United States. ...

The corporation made available $\$ 4,500$ to cover honorarium and all expenses for the period from about June 1, 1930, to February 1, 1931, the period for which the University had approved his leave.

Brookes aided further by writing letters of introduction to the prime minister of Australia and the premiers of the several states in Australia. In his letters he emphasized that "Livingston is one of those loyal Americans who entertain a profound admiration for the spirit and structure of the British Commonwealth of Nations."

Before he left Iowa City in June, Miss Wormer authorized him to spend a maximum of $\$ 500$ from the library book fund while he was abroad. Reaction from his colleagues in the history department as well as from the library staff was that he purchased "a fine lot of material with these funds."

Livingston stopped at Tahiti and Rarotonga during a pleasant voyage across the Pacific Ocean. In New Zealand he visited country fairs, went to horse races and dog trials as well as going through the native villages of the North Island. In addition to doing some research in the Alexander Turnbull Library in Wellington and watching the New Zealand Parliament in session, he spoke to a number of organizations.

After about a month in Wellington, he went to Sydney, Australia, where he spent most of his time in the Mitchell Library, "a store house of historical records." Livingston had the opportunity to use the papers of Alfred Deakin, three-time prime minister of Australia in the early 1900s, and of William M. (Billy) Hughes, prime minister during World War I. Hughes was very interested in Livingston's work and made available his private papers for the period of the war and the peace, including the secret journals of the Imperial 
War Cabinet. No scholar had ever had this opportunity before Livingston.

Livingston asked the Carnegie Corporation for an additional grant so that he could remain and continue his work for another semester. A few days before he was due to sail for home he was informed that the grant could not be extended.

He felt that, in addition to his research, he had learned much about the political situation in Australia. "I have wallowed in it, lived with it, absorbed it, and I think I understand it somewhat."

$\mathrm{He}$ was also able to increase greatly the holdings of Australian documents at the University. Prior to his trip, the exchange agreement had included only those publications subsequent to 1929. Now, as a result of his contacts in Canberra, he acquired a complete set of the Commonwealth parliamentary papers from the beginning in 1901, a complete set of Commonwealth Acts, a complete set of Federal Convention Debates in Sydney, Adelaide, and Melbourne in 1897-98, and a set of the Official Year Book of the Commonwealth. The only charge to The University of Iowa was the shipping charges.

Soon after coming to The University of Iowa, Ross began to give several courses that proved to be popular among the students. These were American Constitutional History, American Diplomatic History, and his principal interest, the History of the British Empire and Commonwealth.

In his courses on the British Empire and American foreign relations, his two favorite subjects were "responsible government" and "manifest destiny," respectively. However, it is very possible that many of his students still have memories of his vividly describing the sheen of his white bull's hide rather than the finer points of his lectures.

One of his students at the University of California at Los Angeles, where Livingston taught as a visiting professor in 1965-66, wrote a paper in which he talked about Ross as a teacher. In part he described him in this manner:

He usually wore either of two ties which like his dark suits were habitually sprinkled with assorted spots, stains, and chalk dust. In general, his appearance was that of a prosperous mid-Westem farmer (which he was) or a small town mayor. This dynamic man never stood still for long. .... he would alternately thunder, squeal, or whisper [as he lectured]. Each classtime I felt as if I were witnessing some unique performance. At any moment, his lectures would soar into the higher vaults of philosophy, religion, or to whatever realm his unpredictable imagination would lead him. 
In view of his booming voice with which he frequently accentuated points of his lectures, it would seem impossible for students to sleep in his classes. But it did happen sometimes. One morning at the close of an 8:00 class, Livingston stopped one of his students and asked, "Are you sick or something? You can't seem to be able to keep awake."

The student replied that he went door-to-door in one section of Iowa City to deliver handbills to earn a little money to help with his expenses. He started at 5:00 A.M. each Thursday morning, the day of the class, and, in spite of his efforts, he could not keep awake after coming in from the wintry cold to a warm classroom. Livingston patted the student on the shoulder and said, "That is all right. You can continue to sleep in my classes anytime, and I will not hold it against you."

Many of Livingston's students continued to hold him in high regard after they graduated and offered him opportunities both before and after his retirement to act as a visiting professor in their colleges and universities. Among those at which he gave courses were Wake Forest, Coe, Creighton, Willamette, the University of California at Los Angeles, and California State College at Long Beach.

Livingston was not only interested in history and government as subjects to be taught. He was also concerned about practical dayto-day politics. In 1922 he offered his assistance to Breckinridge Long in his campaign to defeat Senator James Reed for the Democratic nomination for United States senator from Missouri. "I feel deeply that your success in this campaign," he wrote Long, "is necessary to sustain the great leadership of Woodrow Wilson and the principles for which he so gallantly fought."

Livingston continued to be greatly interested in American politics. Frequent comments in the various letters he wrote provide clues. In 1926 he wrote that his teaching was going along nicely, "and I must tell you that my students in American History do not know as yet what my political bias is and we are as far along now as the reign of king Andrew [Jackson]. Isn't that a feat for a confirmed Democrat?" He continued, "I suppose our task is a more lofty one than training these fellow citizens of ours in any particular bias." Two years later he wrote a friend that he was much pleased to learn that he was getting along well in "this world of sin, sorrow and Republicans."

During the 1928 presidential campaign he was in full support of Governor Al Smith. When Smith was defeated, Livingston wrote him 
that he deeply regretted that "the electorate of this nation failed yesterday to give you and to our great party the victory." Livingston felt that the Democratic campaign had "revitalized our party organization, humanized it, and made it again the great national Liberal organization of America, and along these lines our ultimate success is assured." Ross saw the defeat as due to the "combination of Catholicism, and that I think was a major factor, the wet program and Tammany Hall," which was evidently "too much for the South and middle West."

Livingston thought that the Democratic party had a great opportunity to come back to power in 1932. He felt that the country "has never been so much in need of a great leader as it is now, not so much to bring back immediate prosperity but to give people everywhere confidence in the government." If Roosevelt should fail to win the election, "the bonus army in Washington is only the beginning of a long period of upheaval."

$\mathrm{He}$ was very pleased with the election of Roosevelt. "The new administration pleases me very much; it has the ring of honesty and real ability," he wrote. In another letter he wrote, "The 'New Deal" is breath taking in its speed and President Roosevelt seems to have plenty of fine force and courage. $\mathrm{He}$ is Wilson over-again, even more-Wilson plus the radio."

In 1936 Livingston became a delegate to the Johnson County Democratic Convention. As a member of the Resolutions Committee he wrote the resolutions. Later he attended the state Democratic convention as a delegate. In candid remarks he made later, he did not appear very well impressed with the activities of some of the candidates. The delegates "'milled' up and down the hotel lobby, smoking five cent cigars, shaking hands, and chattering stupidly about post offices, farm relief and the New Deal."

He enjoyed the "holiday" and was able to work, cooperate, and dine with any group without their being aware that he was a professor of history. "I boast of this fact," he wrote, "because it convinces me that I am not 'set' in this groove of stale academic mediocrity." He thought that, if he attempted to do so, he could defeat the two aspirants for nomination for the United States Senate. But, for the present, he decided to remain a professor "unless by chance or good luck" he was sent to Australia or some other country as a diplomatic representative.

In subsequent years he continued to serve as a delegate to the state conventions. As such, he served on the Platform Committee and had much to do with the writing of the state platforms for the party. 
Harry Truman was another Democratic president for whom Livingston had great respect. It seems possible that he may have voted for Eisenhower, at least for the second term. Although remaining a staunch Democrat throughout his life, it was evident in conversations with him that he did not consider the subsequent leadership of the party to be at all comparable with that provided by Wilson, Roosevelt, and Truman.

In 1931 Livingston was expressing the hope to Brookes that it might be possible "to come back to Australia some time as a diplomatic representative." With the election he saw a possibility that this might happen.

He noted with satisfaction that Roosevelt was making use of men in the academic professions. He added, "If Mr. Roosevelt should have any interest in adding me to his army of loyal assistants you can tell him of my work and experience."

A short time later he asked his friends in the Democratic party to support him for a diplomatic post in South Africa, Ireland, or Australia. Many from the party as well as others from the academic world supported him, to no avail.

Congressman Edward Eicher of Iowa told him there would be no new appointments in the diplomatic service at that time (1933). "A definite policy has been adopted to permit the remaining personnel to absorb the work of reductions resulting from resignations or other causes." William Phillips, acting secretary of state, wrote him in December 1933 that no vacancy existed in the post of minister to the Union of South Africa and the United States had no diplomatic mission in Australia.

Livingston continued to be interested in a diplomatic assignment, however. In 1934 he wrote, "I have been a loyal Democrat even here in a Republican state institution." He sought the post in Ireland in 1935 when it became vacant but lost out to a Texas Democrat. Ross went to visit Secretary of State Cordell Hull in September 1935, regarding an appointment to Australia. In this case the United States and Australia did not establish diplomatic relations until 1940. Livingston continued to be interested in joining the American Foreign Service until 1939.

On May 16, 1940, President Roosevelt asked Congress for an additional appropriation for defense. The next day Livingston wrote Joseph Broderick, a friend from World War I days, that he considered the president's speech "a declaration of war." He thought that they might "meet again somewhere in harness. I have a good uni- 
form. I have not forgotten my training. . . even though I am fortysix, I believe I would be useful."

Five months later he wrote that he would be glad to make his services available when the time came that he was needed. In March 1941 he again wrote Broderick, saying, "I must confess to you that I wish very much to participate myself." Broderick replied that he felt their job was to "keep the home fires burning." This did not deter Livingston. In November 1941, he wrote Henry L. Stimson, secretary of war, that he would be "available for whatever service I would be able to perform."

Nothing occurred until 1943. By orders effective August 24 he was directed to proceed to Fort Custer, Michigan, for active duty. He received training there and also at Harvard University and Shrivenham, England, for the military government program. He was in command of a detachment and ready to go to Germany when he met Colonel Cecil Hahn, a former student of his and chief of the History Section of the Eighth Air Force. As a result Livingston was transferred to this unit instead of going to govern some place in Germany.

At the end of the war, the historical unit was transferred to Baltimore and then to Gravelly Point near the Pentagon in Washington, D.C. General Carl A. Spaatz, chief of staff of the U.S. Air Force, decided to make a report to the Joint Chiefs of Staff on his experience in Europe. He selected about 20 air force officers, Livingston among them, to do the job. Ross's assignment was the command relations of Spaatz. After about one month Spaatz decided not to make the report and dismissed all of the officers except Livingston.

Livingston completed a report of about seven hundred pages on the subject that had been assigned to him. It was classified as top secret and locked up. In the 1970s the report was declassified. At the time of his death, Livingston was busily at work revising the project for general publication.

Ross was a man of the soil. Over a period of several years he had purchased 458 acres of land in Missouri. During his free time at the University, he would go to his "ranch" and get a "good workout." He welcomed the chance to enjoy the fields of clover, the woodland pastures, and the clear spring water.

Sometimes he would hitch his truck to a harrow and sow some clover seed. It helped his spirit to "kick up the dust in that way." Another time he replastered the house. "You should see me wield 
the trowel and the mortar board. I really became quite skillful." He built fences, made ponds and terraces, built sheds, looked after his cattle, and watched his tenant farmer turn the soil with his tractor. Usually he soaked up a lot of sunshine and worked off surplus weight. As a result he could report, "Aside from the callouses on my hands and the sunburn, I am in reasonably good condition."

Livingston was a colorful and sometimes unpredictable person. $\mathrm{He}$ was frequently very straightforward in his remarks. In 1930 he noted in his diary: "Got 'Serra Tonic' today \& it is $22 \%$ alcoholl Prohibition is a damn farce."

When he was invited to teach summer school at the University of Washington in 1929, he began making preparations for the trip early. He had bought a new Dodge which was broken in and working in fine shape by the time he was ready to go. He planned to equip the car with a tent, plenty of blankets, fishing tackle and perhaps a high-powered rifle. His plan was to take 22 days and make a trek out of it. "Driving in the open air is very much to my liking, as well as sleeping during the cool mountain nights, and the camp fire of the early dawn," he wrote.

Livingston loved good food, but some of his favorites were a bit unusual. Frequently, he would ask a waitress for a "razzle-dazzle" and receive a blank look in return. After a short time he would explain that it was buttermilk with two scoops of ice cream-any flavor would do. In the spring he would suggest to dinner guests that they try another of his specialties-fresh scallions from his garden with a dab of butter on each bite.

Of all his activities and achievements, W. Ross Livingston probably took the most pride in two of them. First, he was very proud of his "boys" as he called them, undergraduates and graduates who held responsible positions in the government and in academic institutions. Secondly, he was always referring to his accomplishments in bringing together at The University of Iowa a collection of documents pertaining to the British Commonwealth-one of the best, if not the best, in the United States. 